\title{
Insect Pests of Grapes in Florida ${ }^{1}$
}

\section{Oscar Liburd, Gisette Seferina and Scott Weihman ${ }^{2}$}

Florida has approximately 1,500 acres of grapes. With increased funding from the Viticulture Advisory Council (VAC) to establish new wineries throughout the state, production is expanding rapidly. Muscadine grapes, Vitis rotundifolia Michx are the principal type of grapes cultivated in Florida. Only a few acres $(<200)$ of bunch grapes, Euvitis spp., are grown in Florida. In general, grapes are susceptible to many insect pests. Some of the common insect pests attacking grapes in Florida include: grape root borer, glassy-winged sharpshooter, grape flea beetle, grapevine aphid, grape leaffolder, grape curculio, and grape phylloxera.

\section{Grape Root Borer, Vitacea polistiformis (Harris)}

The grape root borer (Figure 1) is the most serious threat to grapes in Florida (Liburd and Seferina 2004). It is a member of the moth family Sesiidae. Adults are brown moths with thin yellow bands on the abdomen and resemble some paper wasps. The front wings are brown while hind wings are transparent. The eggs hatch on the soil surface and the larvae tunnel into the root system. Borer damage causes reduced vine growth, smaller leaves and reduced berry size. Because damage is restricted to below-ground, problems often go unnoticed until the vines start to die. Damage ranges from just a few feeding sites to complete root destruction. Grape root borer presence can be determined by detection of shed pupal skins at the base of the vines. Cultural methods for control of grape root borer include mounding soil under vines just after pupation in order to reduce adult emergence. Proper weed management is also important for reducing potential egg laying sites and to increase larval mortality due to desiccation. Two species of Heterorhabditis nematodes have shown promise as biological control agents against grape root borer larvae. Growers can monitor grape root borer populations by hanging traps (Figure 2) baited with grape root borer pheromones. Pheromone-baited traps are recommended for monitoring adult moths. These traps should be placed about $100 \mathrm{~m}$ apart inside the vineyard and along adjacent woodland boundaries. Monitoring information may be useful for timing insecticide applications, and it is important to have insecticides on the soil surface at the time of egg hatch because contact insecticides are ineffective once larvae reach the root system.

1. This document is Fact Sheet ENY-713, a series of the Entomology and Nematology Department, Florida Cooperative Extension Service, Institute of Food and Agricultural Sciences, University of Florida. Publication date: September 2004. Please visit the EDIS Website at http://edis.ifas.ufl.edu.

2. Oscar Liburd, Gisette Seferina, Scott Weihman, Department of Entomology and Nematology, Institute of Food and Agricultural Sciences, University of Florida, Gainesville, FL.

The Institute of Food and Agricultural Sciences (IFAS) is an Equal Employment Opportunity - Affirmative Action Employer authorized to provide research, educational information and other services only to individuals and institutions that function without regard to race, creed, color, religion, age, disability, sex, sexual orientation, marital status, national origin, political opinions or affiliations. For information on obtaining other extension publications, contact your county Cooperative Extension Service office. Florida Cooperative Extension Service / Institute of Food and Agricultural Sciences / University of Florida / Larry R. Arrington, Interim Dean 


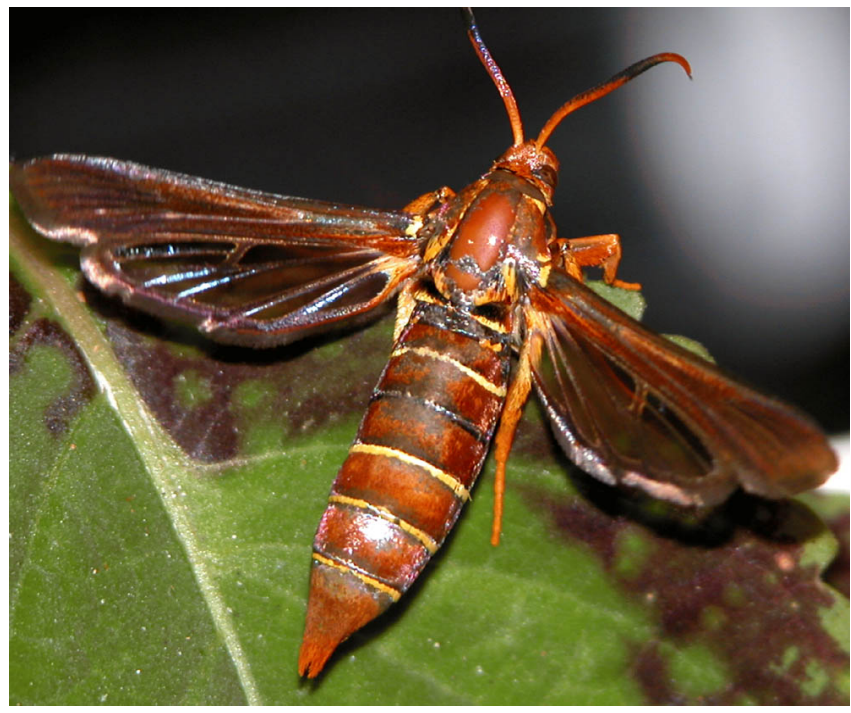

Figure 1. Adult female grape root borer. Credits: Scott Weihman, University of Florida

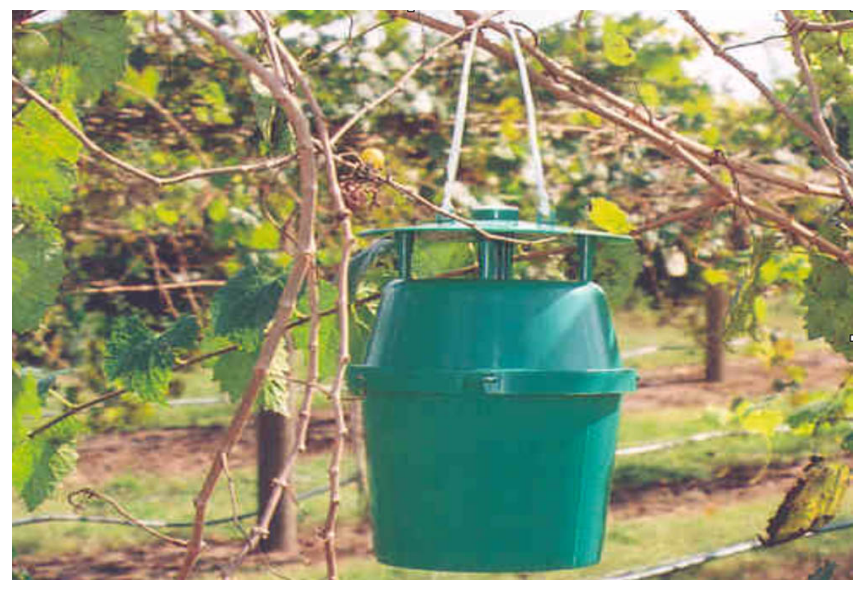

Figure 2. Grape root borer monitoring trap. Credits: Scott Weihman, University of Florida

\section{Glassy-Winged Sharpshooter, Homalodisca coagulata (Say)}

This leafhopper is native to the southeastern United States. The glassy-winged sharpshooter (Figure 3) feeds on grapevine stems as opposed to leaves. Females lay eggs in groups of 10-20 on the underside of leaves, just under the surface. The glassy-winged sharpshooter vectors the bacterium Xylella fastidiosa, which causes Pierce's disease in grapes. Pierce's disease (Figure 4) is considered the most serious threat to viticulture throughout the United States. It is the single most formidable obstacle to the growing of European-type (vinifera) grapes. The disease is less prevalent where winter temperatures are colder, such as at higher altitudes, further inland from ocean influences, and at more northern latitudes. It has been found in all southern states that raise grapes commercially: from Florida to California, and in Mexico and Central America. In general, muscadine grapes are resistant to $X$. fastidiosa, which may be responsible for the absence of Pierce's disease in some places, including Florida. Early symptoms of Pierce's disease include wilting, which is caused by bacterial growth that blocks the flow of xylem in affected plants (Brlansky et al. 1983). Subsequent damage includes discolored leaf margins, shrivelled fruit, leaf drop, and irregular maturation of new canes. Host plant resistance methods, which focus on planting vines resistant to $X$. fastidiosa may reduce the incidence of Pierce's disease.

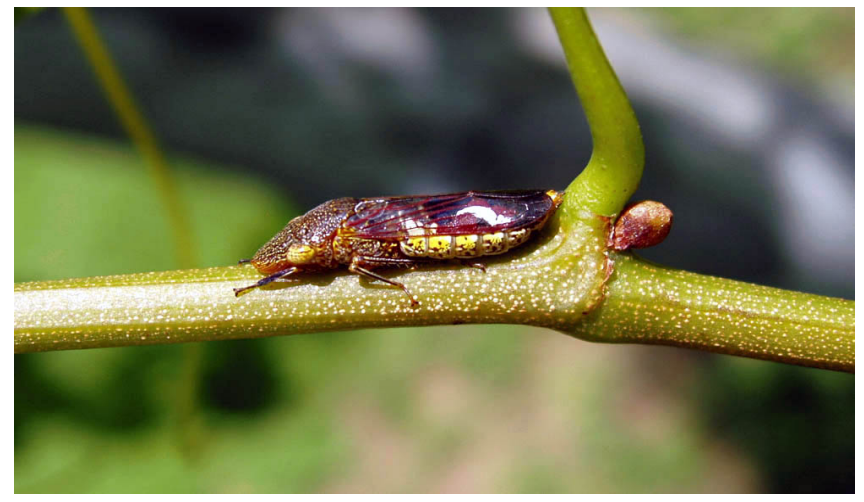

Figure 3. Glassy-winged sharpshooter. Credits: Scott Weihman, University of Florida

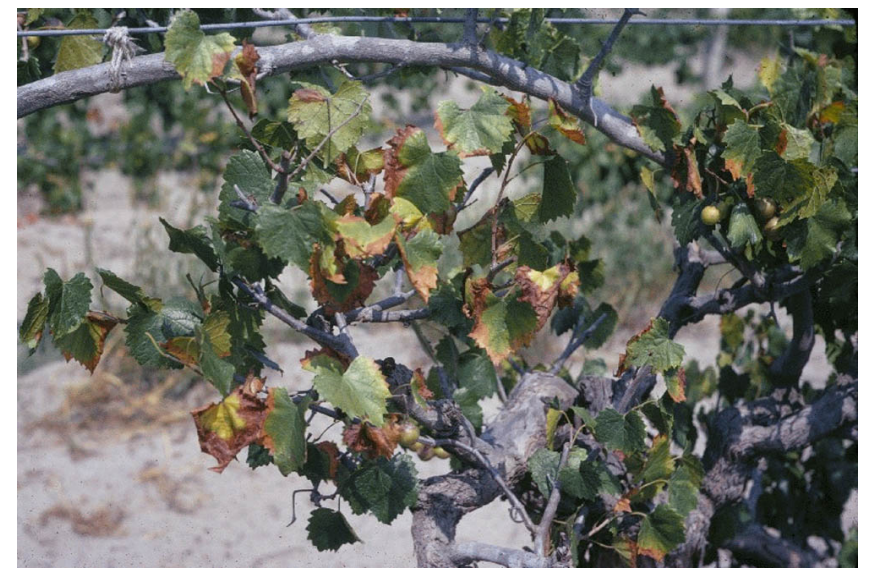

Figure 4. Pierce's disease on grape leaf. Credits: Don Hopkins, University of Florida, Apopka

\section{Grape Flea Beetle, Altica chalybea (IIliger)}

Grape flea beetle (Figure 5) is found in the eastern two-thirds of the United States. Like most members of the family Chrysomelidae, it feeds 
primarily on foliage. Adults are dark metallic greenish-blue jumping beetles about 4-5 mm (1/5 inch) long. They feed on buds and unfolding leaves. The larvae are brownish and marked with black spots. Larvae feed on flower clusters and skeletonize leaves. Damage is often restricted to vineyard borders, particularly near wooded areas. To date, no monitoring guidelines have been developed. Some biological and neonicotinoid insecticides will reduce high populations of flea beetles during the growing season.

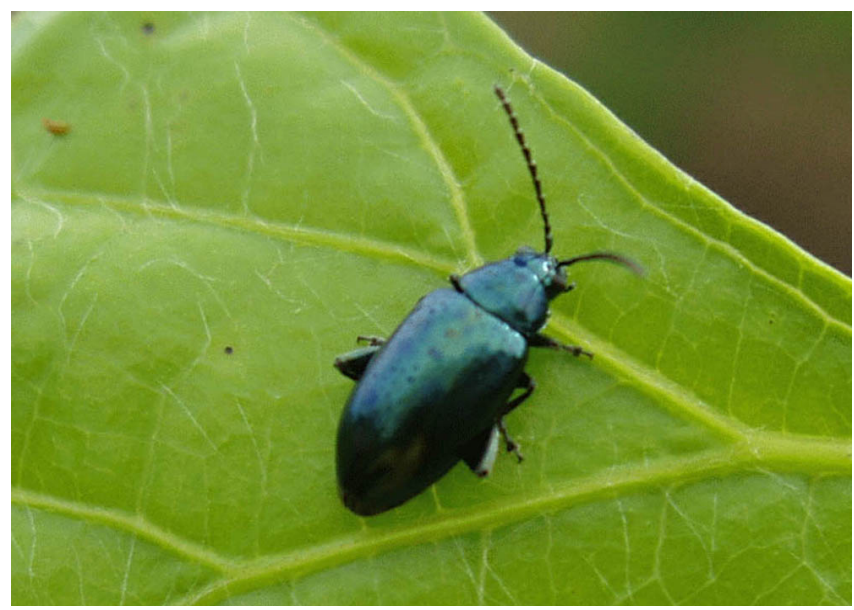

Figure 5. Grape flea beetle. Credits: Scott Weihman, University of Florida

\section{Grapevine Aphid, Aphis illinoisensis (Shimer)}

Aphids feed on the foliage and vines of grape plants, but more serious injury results from the infestation of the developing fruit clusters. Dry weather contributes to the growth of aphid populations.

The grapevine aphid (Figure 6) is usually not important enough to necessitate specific treatments. Good production practices result in grapevines that are of sufficient vigor to tolerate some attack by aphids. Aphids are attacked by predators like ladybird beetle adults and larvae, and lacewing larvae that regulate their population.

\section{Grape Leaffolder, Desmia funeralis (Hübener)}

Grape leaffolder moths (Pyralidae) (Figure 7) are brownish black, with two white spots on the

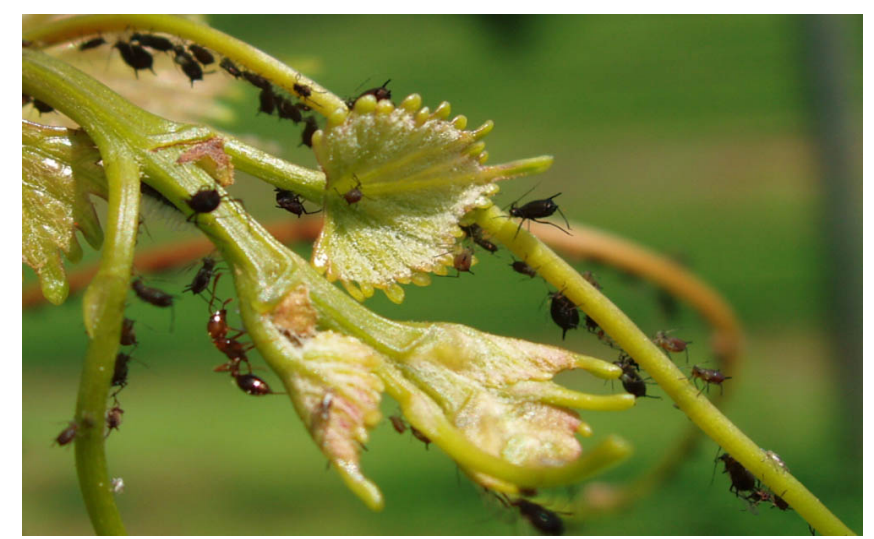

Figure 6. Grapevine aphids. Credits: Scott Weihman, University of Florida

forewings and two white stripes across the abdomen. The larvae (Figure 8) are about 10-15 mm (5/8- 6/8 inch) long when mature. The larvae fold the leaves to form a protective layer in which they feed. Damage from the third generation can be severe enough to cause complete defoliation (Liburd and Finn 2004). The moth can be monitored with tent-shaped traps baited with terpinyl acetate and with black light traps. In general, populations of grape leaffolder are regulated by the presence of wasp parasitoids, particularly Bracon cushmani (Muesebeck). Insecticide sprays are generally most effective against early instars.

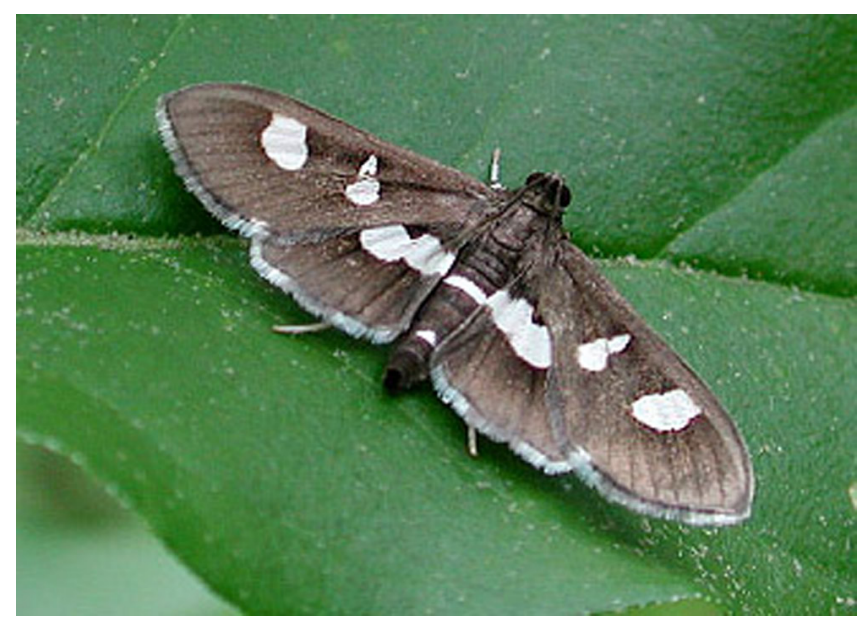

Figure 7. Grape leaffolder moth adult. Credits: John Himmelman, Discovering Moths, http://booksandnature.homestead.com/moth115.html

\section{Grape Curculio, Craponius inaequalis (Say)}

This curculio has been reported throughout eastern North America. An occasional pest of mature 


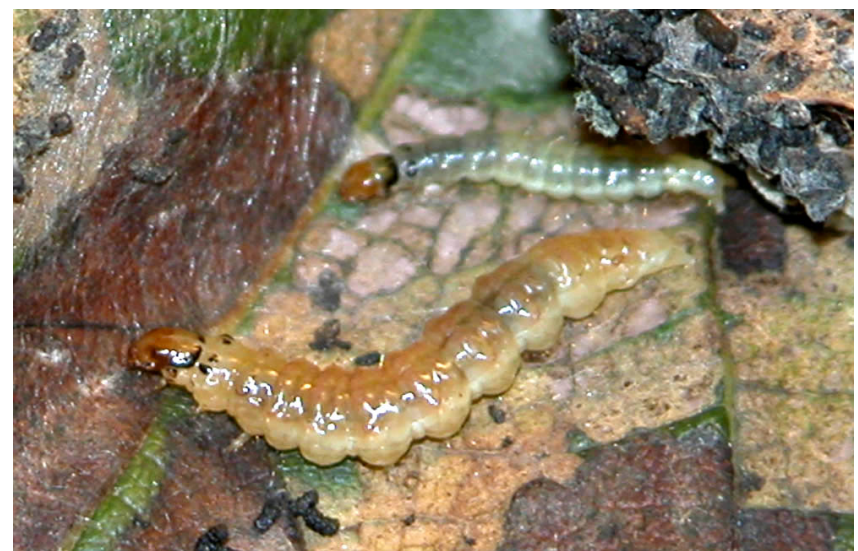

Figure 8. Grape leaffolder larvae. Credits: Scott Weihman, University of Florida

grape berries, the adult grape curculio (Figure 9) is a foliage feeder, leaving a characteristic zigzag pattern on the undersurface of grape leaves (McGiffen and Neunzig 1985). It lays eggs in the berry, where larvae feed on the fruit as well as on the seeds. They are distinguished from the caterpillars of the berry moth, another grape berry feeder, by their lack of true legs. Proper orchard sanitation is usually adequate to prevent significant infestations. Pesticide applications are required whenever the insects or damage are present.

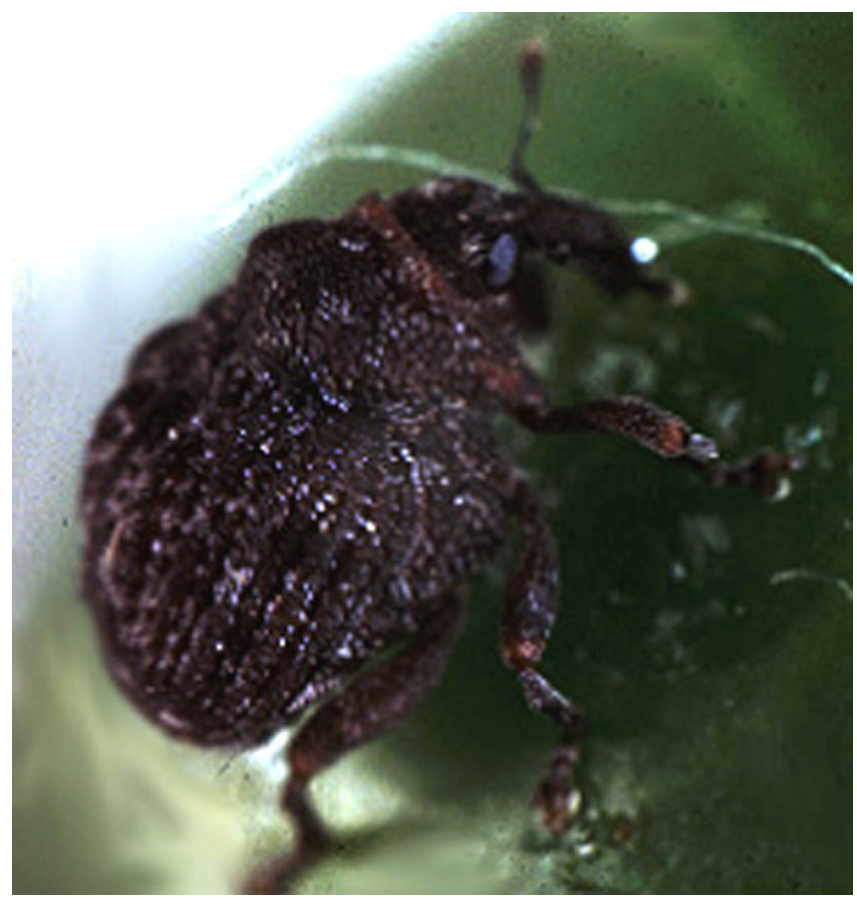

Figure 9. Grape curculio. Credits: Virginia Cooperative Extension Service

\section{Grape Phylloxera, Daktulosphaira vitifoliae (Fitch)}

Grape phylloxera is native to North America and occurs in many wild species of grapes in Florida as well as other areas of the Southeastern United States. The presence of grape phylloxera is easily recognized due to the characteristic galls that develop on the leaves (Figure 10). Leaf galls usually develop on the underside of vine leaves and are about 5-7 $\mathrm{mm}$ in diameter. Leaf (aerial) phylloxera does little harm and does not necessarily take up residence in all Florida vineyards. These galls also occur on the roots but they are not readily apparent. Root galls are small knots (enlarged areas) on the roots, which interfere with the roots ability to absorb water and mineral salts (Flaherty et al. 1992). An aphid-like insect is responsible for causing the symptoms of grape phylloxera. Many native American grapes are tolerant or resistant to root attack and are used as rootstocks for European grapes in other parts of the country.

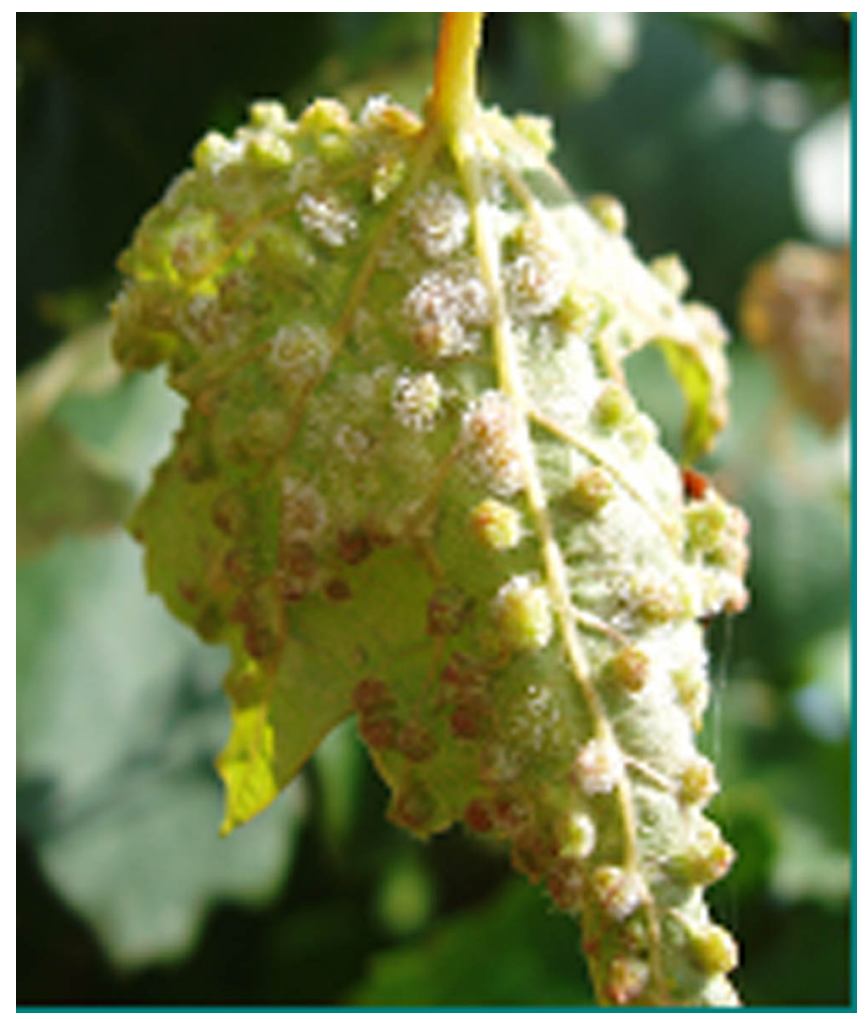

Figure 10. Grape aerial phylloxera. Credits: Scott Weihman, University of Florida 


\section{References}

Brlansky, R. H., L. W. Timmer, W. J. French and R. E. McCoy. 1983. Colonization of the sharpshooter vectors, Oncometopia nigricans and Homalodisca coagulata by xylem limited bacteria carriers of xylem limited bacterial disease. Phytopathology. 73:

530-535.

Flaherty, D. L., P. L. Christensen, T.W. Lanini, J. J. Marois, P.A. Phillips, and L.T. Wilson. 1992. Grape pest management. $2^{\text {nd }}$ ed. Publication \# 3343. University of California, Division of Agriculture and Natural Resources, Oakland, California.

Liburd O. E., and E. M. Finn. 2004. Small fruit pests and their management. In: J. L. Capinera (ed.), Encyclopedia of Entomology. Vol. 3 [P-Z]. Pages 2019-2022. Kluwer Academic Publishers, Dordrect, The Netherlands.

Liburd, O. E., and G.G. Seferina. 2004. Grape root borer: Life stages and IPM strategies in Florida. Fact Sheet SP 330: Entomology and Nematology Dept., University of Florida, Gainesville, FL. 2 pp.

McGiffen, K. C., and H. H. Neunzig. 1985. A guide to the identification and biology of insects feeding on Muscadine and bunch grapes in North Carolina. Pp 34 - 38. North Carolina Agricultural Research Service, North Carolina State University, Raleigh, North Carolina. 